\title{
Increased ovulation rate in gilts after oral administration of epostane
}

\author{
S. L. Fu, G. D. Dial*, D. M. Keister† and W. R. Butler \\ Department of Animal Science, Cornell University, Ithaca, NY 14853, USA; \\ * School of Veterinary Medicine, North Carolina State University, Raleigh, NC 27606, USA; and \\ $\dagger$ Sterling Research Group, Columbia Turnpike, Rensselaer, NY 12144, USA
}

\begin{abstract}
Summary. In Phase I of this study to enhance ovulation rate and hence litter size, gilts received 0 (sham control), $0.625,1 \cdot 25,2.5$ or $5 \cdot 0 \mathrm{mg}$ epostane $/ \mathrm{kg}$ body weight on Days 10,11 and 12 of the oestrous cycle ( 5 gilts/group). After epostane treatment, plasma progesterone concentrations were reduced $(P<0.01)$ in a dose-related manner, \% progesterone decline $=21 \cdot 30 \times \sqrt{ }($ dose $)+10 \cdot 45, \mathrm{R}^{2}=0 \cdot 70$, but recovered to pretreatment levels by $24 \mathrm{~h}$. In Phase II the effects of epostane on ovulation rate and litter size were tested at two study centres. At each centre 108 gilts were treated with the same doses of epostane as used in Phase I and the doses were given for 7 days (Days 15-21) or 12 days (Days 10-21) during the first oestrous cycle. Gilts were inseminated twice during the oestrus after treatment and were slaughtered 30 days later. Mean $( \pm s . d$. ovulation rate was $16 \pm 2 \cdot 7(\mathrm{~N}=8)$ and $21 \pm 4.0(\mathrm{~N}=61)$ for control and epostanetreated gilts in Centre $A$ and $12 \pm 2 \cdot 4(\mathrm{~N}=5)$ and $17 \pm 3 \cdot 8(\mathrm{~N}=55)$ respectively in Centre B $(P<0.01$ for both) and was dose related (ovulation rate $=3.38 \times$ $\sqrt{ }($ dose $\left.)+16 \cdot 17, \mathrm{R}^{2}=0 \cdot 31\right)$. The effects of 7 - or 12-day epostane treatment on ovulation rate were not different $(P>0.05)$, indicating that effects of treatment after Day 14 of the oestrous cycle are most important to subsequent ovulation frequency. The number of viable embryos was not significantly increased after epostane treatment $(P>0.05)$. We conclude that treatment with epostane, $3 \beta$-hydroxysteroid dehydrogenase inhibitor, late in the oestrous cycle increases ovulation rate in gilts.
\end{abstract}

Keyn'ords: gilt; epostane; ovulation rate; progesterone; corpora lutea

\section{Introduction}

Of the many factors which affect litter size in pigs, the initial constraint is the ovulation rate which averages 15 (Blichfeldt \& Almlid, 1982; King \& Williams, 1984; Pope \& First, 1985). A direct relationship exists between the number of corpora lutea $(\mathrm{CL})$ and the number of live embryos up to 14 as each additional corpus luteum from 3 to 18 was associated with an additional 0.756 embryo (Wu et al., 1987).

In pigs as in other species, ovulation rate is limited by the number of follicles that mature to ovulation. Evidence has been presented for several species indicating that luteinizing hormone $(\mathrm{LH})$ is causally related to development of preovulatory follicles and to the number of follicles which subsequently ovulate. Perhaps the most important direct evidence concerning $\mathrm{LH}$ and follicular recruitment is that $\mathrm{LH}$ administration during the oestrous cycle induces superovulation in the cyclic hamster and guinea-pig (Garza et al., 1984). Epostane, an orally active 3 $\beta$-hydroxysteroid dehydrogenase inhibitor in $\mathrm{CL}$, interrupts progesterone synthesis and therefore its negative feedback, resulting in increased circulating LH concentrations in cattle (Peters \& Lamming, 1986). In a subsequent report in sheep, inhibition of mid-luteal phase progesterone production with 
epostane resulted in a significant enhancement of both ovulation rate and lambing rate (Webb, 1987).

Follicular recruitment for ovulation in pigs occurs between Days 14 and 16 of the oestrous cycle (Clark et al., 1982; Foxcroft \& Hunter, 1985). For the present study, it was proposed that increased LH secretion resulting from epostane treatment during follicular recruitment and maturation would enhance ovulation rate in gilts. The dose-response inhibitory effects of epostane on progesterone secretion during the oestrous cycle in gilts were determined in Phase I. In Phase II epostane was given for 7 or 12 days before mating to measure the effects on ovulation rate and embryo numbers.

\section{Materials and Methods}

Prepubertal Yorkshire-Landrace cross-bred gilts weighing approximately $90 \mathrm{~kg}$ were selected for the study since this is the size at which oestrus can be reliably induced after exposure to adult boars. Gilts were housed in groups of $6-12$ in indoor pens with free access to water and feed. They were acclimatized to the facilities for 1-3 weeks before study and exposure to boars. As gilts were identified in oestrus, they were randomly assigned to treatment groups.

Phase $I$. The 25 gilts were assigned across 5 groups and received 0 (sham control), $0.625,1.25,2.5$ or $5.0 \mathrm{mg}$ epostane/kg body weight once daily on Days 10,11 and 12 of their first oestrous cycle (Fig. 1). Epostane was provided by Sterling Research Group (Rensselaer, NY, USA) as $12.5 \%$ active granules. Gilts were fed and housed individually. Epostane was given at approximately the same time each morning $(10: 30 \mathrm{~h})$ and most gilts ate the drug mixed in a small amount of feed within $30 \mathrm{~min}$. Before Day 8 of the oestrous cycle, gilts were fitted with an indwelling ear vein (or vena cava) vinyl cannula under sedation. The cannula was filled with sterile saline containing $500 \mathrm{IU}$ heparin/ml and was taped to the animal's back for ease of sampling. Blood samples $(5 \mathrm{mi})$ were collected once daily on Days $8,9,13$ and 14 and 4 times daily during treatment on Days 10,11 and 12 (Fig. 1). Blood samples were put into tubes containing saturated sodium citrate $(0.25 \mathrm{ml})$ and immediately centrifuged $(1200 \mathrm{~g})$. Plasma was stored at $-20^{\circ} \mathrm{C}$ for hormone assays. Concentrations of plasma progesterone were determined by radioimmunoassay (RIA; Nara \& First, 1981) using ${ }^{125}$ I-labelled progesterone (Amersham Corp., Chicago, IL, USA). The mean intra-assay coefficient of variation (CV) was $19.1 \%$ and the inter-assay $\mathrm{CV}$ was $17.5 \%$. The lower limit of detection was $100 \mathrm{pg} / \mathrm{ml}$ using $50 \mu \mathrm{l}$ plasma samples. To assess possible effects of epostane on adrenal steroidogenesis, plasma concentrations of cortisol were determined by RIA (Krey et al., 1975). The mean intra-assay CV was $7.8 \%$ and inter-assay CV was $11 \cdot 1 \%$. The minimum sensitivity of the assay was $20 \mathrm{pg}$ per tube.

Phase II. This phase of the study was conducted concurrently at Cornell University (Centre A) and North Carolina State University (Centre B). At each centre, pubertal gilts $(\mathrm{N}=108)$ were assigned at first oestrus to 9 groups (12/group) in a completely randomized design (Fig. 1). Four groups of gilts were treated with epostane (0.625, $1.25,2.5$ and $5.0 \mathrm{mg}$ epostane $/ \mathrm{kg}$ body weight) on Days $10-21$ of the first oestrous cycle and 4 groups of gilts were treated with the same doses on Days 15 2l. The remaining group of gilts served as sham-treated controls. Epostane was given orally at approximately $08: 30 \mathrm{~h}$. Within each treatment group 6 gilts were chronically cannulated for intensive blood collection. These procedures and hormone analyses will be reported elsewhere. Oestrous behaviour was checked by boar exposure twice daily at $08: 30 \mathrm{~h}$ and 18:00 h. All gilts were inseminated artificially 24 and $36 \mathrm{~h}$ after the onset of second oestrus (the oestrus after treatment). Semen was collected from 2 boars of proven fertility, mixed and diluted. The gilts were slaughtered 30 days after the first insemination and the uterus and ovaries were removed for determination of the number of viable and resorbing embryo sites and number of CL.

Statistical analysis. In Phase I, the plasma progesterone and cortisol concentrations were analysed as a split plot for repeated measures (Snedecor \& Cochran, 1980). Independent variables were treatment, gilt-within-treatment (error term for testing treatment effects), sampling time and interaction between treatment and sampling time. The difference in mean hormone concentration in the sham-treated control group from the overall mean for the other 4 groups with time after epostane treatment was compared by F-test (Snedecor \& Cochran, 1980). The difference between pre-treatment baseline and the average hormone level within $12 \mathrm{~h}$ after treatment (combined 4-, 8- and 12-h samples) in each group was evaluated by $t$ test. Next the percentage change of hormone concentrations from baseline until within $12 \mathrm{~h}$ (combined 4-, 8- and 12-h samples) after treatment was calculated and epostane dose levels were transformed by square-root for fitting to a linear model (Neter et al., 1983). Log transformation of dose levels which is typically used in similar situations yielded lower $R^{2}$ values and was not considered further.

In Phase II, the main effects of centre, dose level of epostane, treatment periods and appropriate interactions were evaluated using general linear model (GLM) procedures (SAS, 1985) for the following dependent variables: ovulation rate, oestrous cycle length, number of implantation sites, number of embryos, conception rate, embryonic resorption rate, the ratio of number of implantations to the number of $\mathrm{CL}$ and the number of gilts with cystic follicles. The embryonic resorption rate was computed as: ((no. of implantation sites) - (no. of embryos))/(no. of implantation sites) $\times 100$. If any dependent variable was significant $(P<0 \cdot 05)$, then means for the parameter were compared with 
PHASE I

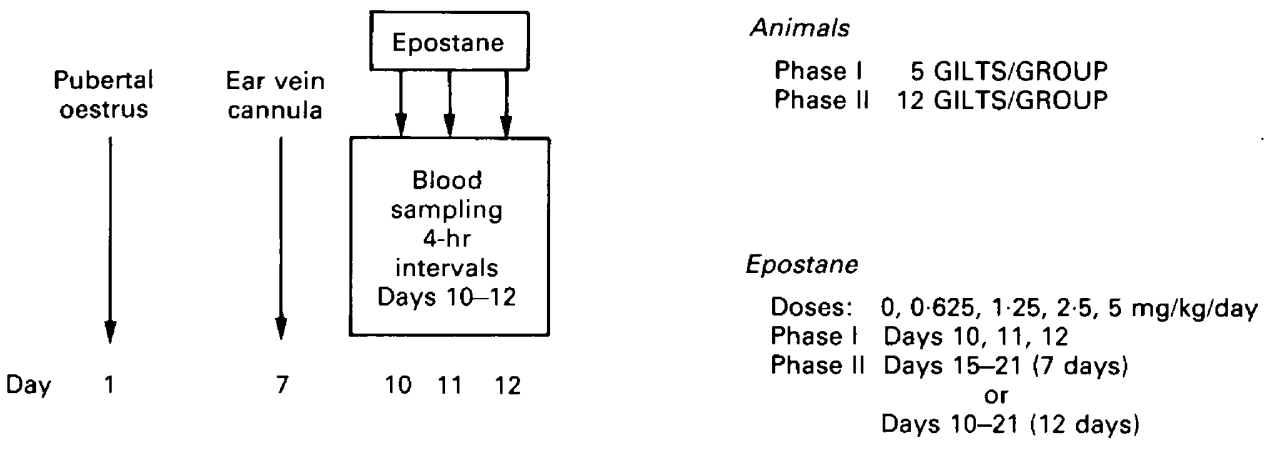

PHASE ॥

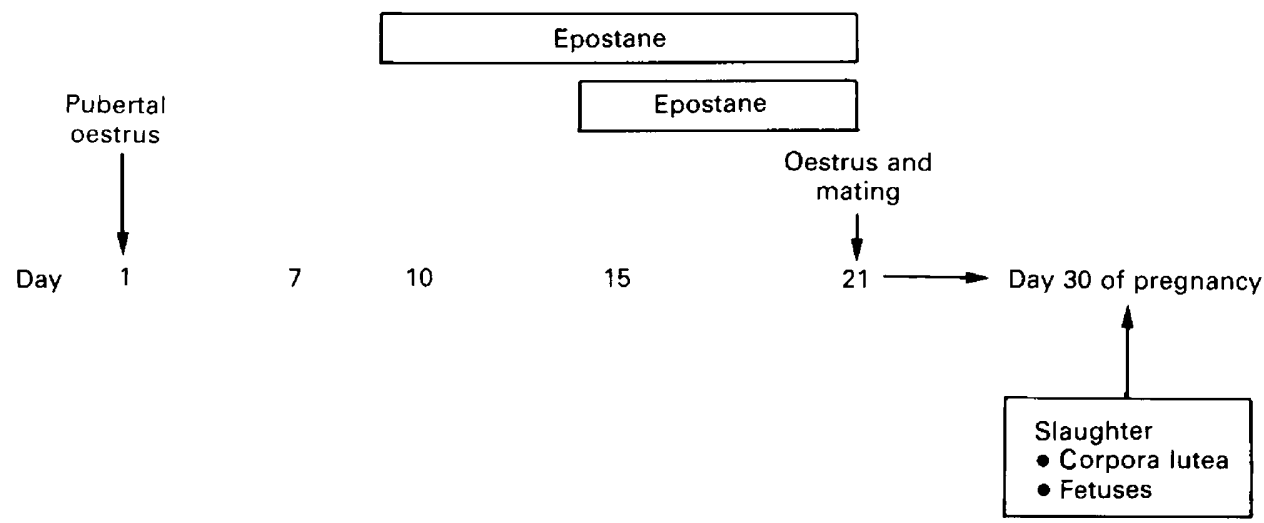

Fig. 1. The experimental design for Phases I and II.

Duncan's multiple comparison (Snedecor \& Cochran, 1980). The number of cystic follicles, defined as large fluidfilled follicular structures lined with yellow luteinized tissue, was recorded at Centre A only and was analysed by $t$ test.

\section{Results}

\section{Phase I}

The overall means for plasma progesterone concentrations were not significantly different among the 5 treatment groups $(P>0.05)$, but the interaction between epostane dose levels and sampling time relative to treatment was significant $(P<0.01)$. Before epostane treatment on Days 8,9 and 10 , the concentration of plasma progesterone in the control group was not statistically different from the overall mean of the treatment groups $(P>0.05)$. In controls, plasma progesterone concentrations before and after sham treatment were not different $(P>0.05)$. At 4,8 and $12 \mathrm{~h}$ after epostane treatment on Days 10-12, plasma progesterone concentrations in treated gilts were significantly lower than in controls $(P<0.01$, Fig. 2$)$. The inhibitory effects of epostane on progesterone was usually maximum at $4 \mathrm{~h}$ after treatment. Lower progesterone concentrations were maintained through $12 \mathrm{~h}$, but recovery had begun. The linear regression between the \% decline in progesterone concentrations within $12 \mathrm{~h}$ (combined data for 4,8 and $12 \mathrm{~h}$ ) and the dose of epostane (transformed by square root) was significant $(P<0.01): \%$ progesterone decline $=$ 
$21.30 \times \sqrt{ }($ dose $)+10.45$ and $\mathbf{R}^{2}=0.70$. The decline in progesterone concentrations from premedication baseline was maximally $-63 \%$ in the group treated with $5.0 \mathrm{mg}$ epostane $/ \mathrm{kg}$ body weight. By $24 \mathrm{~h}$ after treatment, plasma progesterone concentrations had recovered to pre-treatment values $(P>0.05)$ in all 4 treatment groups (Fig. 2). On Day $14(48 \mathrm{~h}$ after the third epostane treatment) the concentrations of plasma progesterone in treated gilts were similar to the normal values before treatment and were not significantly different from those of controls $(P>0.05)$.

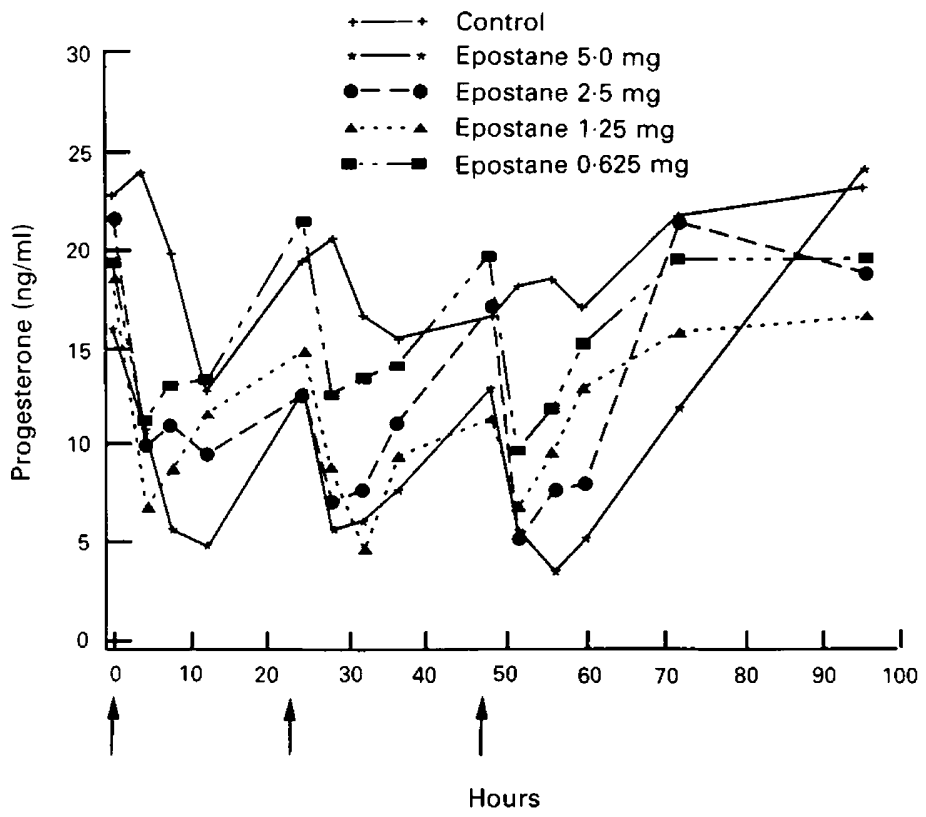

Fig. 2. Plasma progesterone concentrations in gilts after epostane treatment (arrows). Blood samples were collected daily (Days 8 to 14 at $10: 30 \mathrm{~h}$ ) and at 4,8 and $12 \mathrm{~h}$ after epostane treatment $(10: 30 \mathrm{~h})$ on Days 10, 11 and 12 of the oestrous cycle. There were 5 gilts/group.

Plasma cortisol concentrations were not significantly different $(P>0.05)$ among the 5 treatment groups, but varied by sampling interval in a diurnal pattern (data not shown). The highest plasma cortisol concentration occurred each morning at 10:30 h. The \% decline of plasma cortisol concentrations in the afternoon was unrelated to dose level of epostane $(P>0.05)$.

\section{Phase II}

Conception rate and oestrous cycle length. After epostane treatment, 103 and 100 gilts at Centre $A$ and Centre $B$ returned to oestrus and were inseminated, with $67 \%$ and $60 \%$ becoming pregnant at Centre $A$ and Centre B, respectively (Table 1). Conception rate was not significantly different between treatment periods ( 7 vs 12 days, $P>0.05$ ). Only in Centre A for $2.5 \mathrm{mg}$ epostane $/ \mathrm{kg}$ body weight was conception rate $(47 \%$ combined data for 7 - and 12-day treatments) significantly lower $(P<0.05)$ than for other doses. The mean oestrous cycle length was not affected by different dose levels of epostane at either Centre A or B $(P>0.05$, Table 1) and was not significantly different between treatment periods ( 7 vs 12 days, $P>0.05$ ).

Ovulation rate. The ovulation rate was significantly different between centres $(P<0.05)$ and the data were analysed separately. The ovulation rate (mean \pm s.d.) in controls was $16 \pm 2 \cdot 7(\mathrm{~N}=8)$ and $12 \pm 2 \cdot 4(\mathrm{~N}=5)$, at Centres $\mathrm{A}$ and $\mathrm{B}$, respectively, and was significantly increased by epostane treatment to $21 \pm 4.0(\mathrm{~N}=61, P<0.0001)$ and $17 \pm 3.8(\mathrm{~N}=55, P<0.0129)$. The mean ovulation rate for each epostane treatment group was numerically increased from $10 \%$ to $65 \%$ 
Table 1. Conception rate and oestrous cycle length of gilts after epostane treatment in Centres $\mathrm{A}$ and $\mathrm{B}$

\begin{tabular}{|c|c|c|c|c|c|}
\hline \multirow[b]{2}{*}{ Centre } & \multicolumn{2}{|c|}{ Treatment } & \multirow{2}{*}{$\begin{array}{l}\text { No. of gilts } \\
\text { inseminated }\end{array}$} & \multirow{2}{*}{$\begin{array}{l}\text { Conception } \\
\text { rate }(\%)\end{array}$} & \multirow{2}{*}{$\begin{array}{l}\text { Oestrous cycle length } \\
\text { (days; mean } \pm \text { s.d.) }\end{array}$} \\
\hline & Dose $(\mathrm{mg} / \mathrm{kg})$ & Days & & & \\
\hline \multirow[t]{10}{*}{ A } & 0 & & 12 & $61 \cdot 5$ & $21 \pm 1 \cdot 4$ \\
\hline & 0.625 & 7 & 12 & $90 \cdot 9$ & $21 \pm 1 \cdot 6$ \\
\hline & 0.625 & 12 & 11 & $81 \cdot 8$ & $22 \pm 3.5$ \\
\hline & $1 \cdot 25$ & 7 & 11 & $72 \cdot 7$ & $21 \pm 1.9$ \\
\hline & 1.25 & 12 & 11 & $72 \cdot 7$ & $22 \pm 3 \cdot 3$ \\
\hline & $2 \cdot 5$ & 7 & 12 & $58 \cdot 3$ & $22 \pm 1.9$ \\
\hline & $2 \cdot 5$ & 12 & 12 & $33 \cdot 3$ & $22 \pm 1.7$ \\
\hline & $5 \cdot 0$ & 7 & 12 & $75 \cdot 0$ & $24 \pm 2 \cdot 5$ \\
\hline & $5 \cdot 0$ & 12 & 11 & $54 \cdot 6$ & $23 \pm 2 \cdot 0$ \\
\hline & \multicolumn{2}{|c|}{ Sum or mean } & 103 & $\begin{array}{c}67.0 \\
P=0.1519\end{array}$ & $\begin{array}{c}22 \pm 2 \cdot 4 \\
P=0 \cdot 2112\end{array}$ \\
\hline \multirow[t]{10}{*}{ B } & 0 & & 11 & $45 \cdot 5$ & $20 \pm 1 \cdot 1$ \\
\hline & 0.625 & 7 & 11 & $63 \cdot 6$ & $20 \pm I \cdot 0$ \\
\hline & 0.625 & 12 & 11 & $72 \cdot 7$ & $19 \pm 0.8$ \\
\hline & $1 \cdot 25$ & 7 & 11 & $72 \cdot 7$ & $22 \pm 2 \cdot 1$ \\
\hline & 1.25 & 12 & 12 & $58 \cdot 3$ & $19 \pm 2 \cdot 1$ \\
\hline & $2 \cdot 5$ & 7 & 11 & $63 \cdot 6$ & $22 \pm 1 \cdot 7$ \\
\hline & $2 \cdot 5$ & 12 & 10 & $80 \cdot 0$ & $20 \pm 4 \cdot 9$ \\
\hline & $5 \cdot 0$ & 7 & 11 & $54 \cdot 5$ & $22 \pm 0.9$ \\
\hline & $5 \cdot 0$ & 12 & 12 & $33 \cdot 3$ & $21 \pm 3 \cdot 1$ \\
\hline & \multicolumn{2}{|c|}{ Sum or mean } & 100 & $\begin{array}{c}60 \cdot 0 \\
P=0 \cdot 3630\end{array}$ & $\begin{array}{c}20 \pm 2 \cdot 5 \\
P=0 \cdot 1031\end{array}$ \\
\hline
\end{tabular}

compared with controls (Table 2) and was dose related $(P<0 \cdot 01$, Fig. 3). Using the data from Centre A linear regression between ovulation rate and epostane dose levels (transformed by square

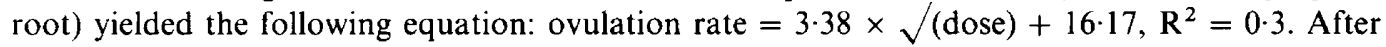
epostane treatment, gilts within each group responded rather uniformly with $92 \%$ and $89 \%$ having more CL than did controls at Centres $A$ and $B$, respectively. The mean ovulation rate ( \pm s.d.) was similar $(P>0.05)$ after 7 or 12 days of epostane treatment at each centre when the data were pooled across dose levels (Centre A, $21 \pm 4.0$ and $21 \pm 4 \cdot 0$; Centre B, $16 \pm 3.5$ and $18 \pm 4 \cdot 0$ ).

Implantation sites and viable embryos. The numbers (mean \pm s.d.) of implantation sites in the control groups at each centre (Table 2) were similar $(P>0.05)$ to those of the epostane treatment groups for Centre A (13 \pm 3.9$)$ and Centre B (12 \pm 4.6$)$. The numbers of viable embryos were also similar between control and epostane treatment groups (Centre A, $12 \pm 3 \cdot 9$ and Centre B, $11 \pm 3 \cdot 8$; $P>0.05$ ). Overall, embryo number did not increase significantly after epostane treatment in either centre, although several groups had higher numbers than in the respective control groups (Table 2).

Ratio of implantation sites to corpora lutea. As shown in Table 2, the ratio showed a general decline as the ovulation rate was increased by epostane treatment $(P<0.01)$. The overall mean for all 8 epostane treatment groups of $59.9 \%$ and $67.6 \%$ was significantly lower $(P<0.05)$ than for controls in Centres A and B, respectively, but the value was not significantly different $(P>0.05)$ for 7 - and 12-day treatment periods $(61.4 \%$ vs $58.2 \%$ in Centre $A$ and $68.0 \%$ vs $66.9 \%$ in Centre B).

Embryonic resorption rate. The mean resorption rates across all 8 epostane treatment groups were $3.7 \%$ and $8.4 \%$ in Centres $\mathrm{A}$ and $\mathrm{B}$, respectively, which were not significantly different $(P>0.05)$ from the control groups $(3.0 \%$ and $3 \cdot 4 \%)$.

Cystic follicles. Although the proportion of gilts with cystic follicles was similar in control and epostane treatment groups $(P>0.05)$, the number (mean \pm s.d.) of cystic follicles per gilt was higher $(P<0.05)$ with epostane treatment $(12 \pm 5 \cdot 2)$ than in controls $(2 \pm 0.7)$. 


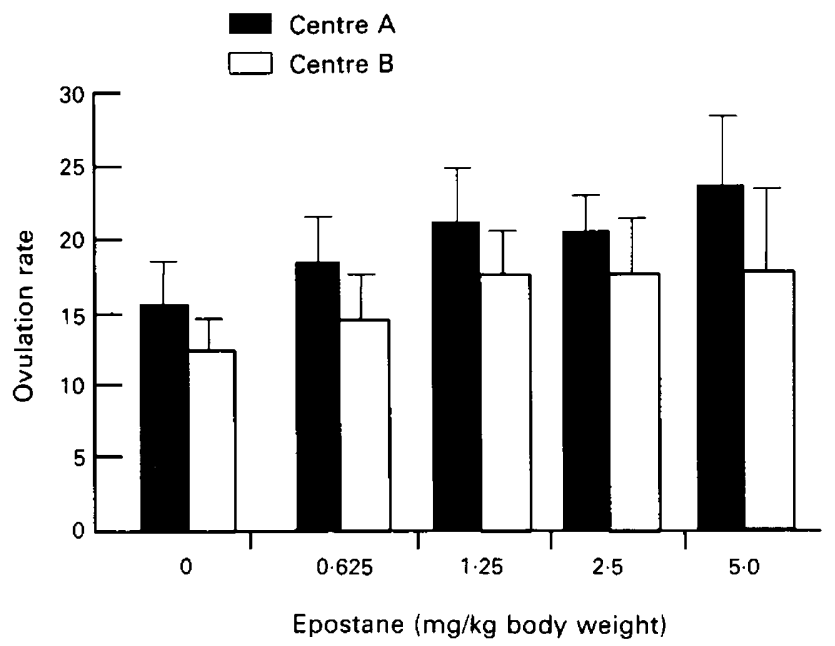

Fig. 3. Ovulation rate (mean \pm s.d.) in pregnant gilts related to dose of epostane (data pooled for 7 and 12 days of treatment) at Centres A and B.

Table 2. Means ( \pm s.d.) for ovulation rate, embryo implantation sites and embryos in pregnant gilts after epostane treatment in Centres $\mathrm{A}$ and $\mathrm{B}$

\begin{tabular}{|c|c|c|c|c|c|c|c|c|c|}
\hline \multicolumn{3}{|c|}{ Treatment } & \multirow[b]{2}{*}{$\begin{array}{l}\text { Ovulation } \\
\text { rate }(\mathrm{A})\end{array}$} & \multirow[b]{2}{*}{$\begin{array}{l}\% \text { Of } \\
\text { control }\end{array}$} & \multirow[b]{2}{*}{$\begin{array}{l}\text { Rank* } \\
\text { (A) }\end{array}$} & \multirow{2}{*}{$\begin{array}{c}\text { No. of } \\
\text { implantations } \\
\text { sites (B) }\end{array}$} & \multirow[b]{2}{*}{$\begin{array}{l}\text { No. of } \\
\text { embryos }\end{array}$} & \multirow[b]{2}{*}{$\begin{array}{l}\text { B:A } \\
(\%)\end{array}$} & \multirow[b]{2}{*}{$\begin{array}{c}\text { Rank* } \\
\text { (B:A) }\end{array}$} \\
\hline $\begin{array}{l}\text { Dose } \\
(\mathrm{mg} / \mathrm{kg})\end{array}$ & Days & No. & & & & & & & \\
\hline \multicolumn{10}{|l|}{ Centre $A$} \\
\hline 0 & & 8 & $16 \pm 2 \cdot 7$ & 100 & $\mathrm{a}$ & $13 \pm 2 \cdot 5$ & $12 \pm 2 \cdot 5$ & $79 \cdot 4$ & a \\
\hline 0.625 & 7 & 10 & $18 \pm 2 \cdot 7$ & 115 & $a b$ & $12 \pm 4.7$ & $11 \pm 4.0$ & $63 \cdot 2$ & $a b c$ \\
\hline 0.625 & 12 & 9 & $19 \pm 3.4$ & 120 & $a b c$ & $14 \pm 3.9$ & $14 \pm 3.9$ & 74.9 & $\mathrm{a}$ \\
\hline $1 \cdot 25$ & 7 & 8 & $20 \pm 3 \cdot 3$ & 127 & bcd & $12 \pm 3 \cdot 3$ & $12 \pm 3.7$ & $61 \cdot 3$ & $a b c$ \\
\hline 1.25 & 12 & 8 & $22 \pm 4 \cdot 3$ & 141 & bcd & $11 \pm 3.6$ & $10 \pm 3 \cdot 2$ & 48.9 & $b c$ \\
\hline $2 \cdot 5$ & 7 & 7 & $21 \pm 2 \cdot 4$ & 135 & bcd & $15 \pm 4 \cdot 3$ & $14 \pm 4 \cdot 5$ & $68 \cdot 7$ & $a b$ \\
\hline $2 \cdot 5$ & 12 & 4 & $19 \pm 1.7$ & 122 & $a b c$ & $13 \pm 3.6$ & $13 \pm 3.9$ & $68 \cdot 8$ & $a b$ \\
\hline $5 \cdot 0$ & 7 & 9 & $24 \pm 4.8$ & 153 & $\mathrm{~cd}$ & $13 \pm 3.7$ & $13 \pm 3.9$ & $54 \cdot 8$ & $a b c$ \\
\hline $5 \cdot 0$ & 12 & 6 & $23 \pm 4 \cdot 6$ & 146 & d & $10 \pm 3 \cdot 3$ & $10 \pm 3 \cdot 1$ & $43 \cdot 5$ & c \\
\hline & & & $P=0.0001$ & & & $P=0.2995$ & $P=\overline{0} .2691$ & $P=0.0188$ & \\
\hline \multicolumn{10}{|l|}{ Centre $B$} \\
\hline 0 & & 5 & $12 \pm 2 \cdot 4$ & 100 & $\mathrm{a}$ & $12 \pm 1 \cdot 3$ & $11 \pm 0.9$ & $96 \cdot 9$ & a \\
\hline 0.625 & 7 & 7 & $13 \pm 2.8$ & 110 & $a b$ & $11 \pm 3.5$ & $11 \pm 3 \cdot 2$ & $83 \cdot 0$ & $\mathrm{a}$ \\
\hline 0.625 & 12 & 8 & $16 \pm 2.9$ & 130 & $a b c$ & $13 \pm 3.8$ & $12 \pm 3 \cdot 0$ & $81 \cdot 1$ & a \\
\hline 1.25 & 7 & 8 & $17 \pm 2 \cdot 2$ & 138 & bc & $14 \pm 4.7$ & $11 \pm 2.7$ & $80 \cdot 6$ & $a b$ \\
\hline $1 \cdot 25$ & 12 & 7 & $19 \pm 3.6$ & 155 & c & $12 \pm 6.4$ & $11 \pm 4.9$ & $58 \cdot 3$ & $a b$ \\
\hline $2 \cdot 5$ & 7 & 7 & $17 \pm 3.4$ & 143 & $b c$ & $11 \pm 4.8$ & $10 \pm 4.8$ & $61 \cdot 3$ & $a b$ \\
\hline $2 \cdot 5$ & 12 & 8 & $18 \pm 4 \cdot 0$ & 147 & $\mathrm{bc}$ & $12 \pm 3 \cdot 2$ & $12 \pm 3 \cdot 2$ & $65 \cdot 7$ & $a b$ \\
\hline $5 \cdot 0$ & 7 & 6 & $16 \pm 4.9$ & 134 & $a b c$ & $7 \pm 5 \cdot 2$ & $7 \pm 5 \cdot 1$ & 44.9 & $\mathrm{~b}$ \\
\hline $5 \cdot 0$ & 12 & 4 & $20 \pm 5.7$ & 165 & c & $12 \pm 2 \cdot 2$ & $11 \pm 3 \cdot 4$ & 60.5 & $a b$ \\
\hline & & & $P=0.0129$ & & & $P=0.3775$ & $P=0.3736$ & $P=0.0461$ & \\
\hline
\end{tabular}

*Significance levels $(P=0.05)$ for Duncan's multiple comparisons within columns; values with the same rank are not statistically different. 


\section{Discussion}

The present study clearly shows that epostane treatment significantly increases ovulation rate in gilts. This is the first demonstration that this inhibitor of progesterone secretion will cause an enhancement of ovulation rate in a multiple ovulating species with a magnitude similar to the effect described previously in sheep (Webb, 1987). The enhancement of ovulation rate in gilts was due to consistent increases of 1-6 more corpora lutea after epostane treatment in $90 \%$ of the pregnant gilts, rather than to only some gilts showing excessive numbers of ovulations (Hunter, 1980). Increased ovulation rate was directly related to the dose level of epostane. Ovulation rate was increased similarly, regardless of whether epostane treatment began on Day 10 or Day 15 of the oestrous cycle. This confirms that recruitment of follicles destined for ovulation probably occurs after Day 14 of the oestrous cycle (Clark et al., 1982; Foxcroft \& Hunter, 1985; Foxcroft, 1987). The relative effect of epostane on ovulation rate was similar at both Centres, in spite of a significant difference between the inherent ovulation rate for the gilt populations at each centre.

Overall, the number of viable embryos was not significantly increased after epostane treatment. Ovulation rate among epostane groups increased proportionately more than the number of viable embryos, resulting in a lower ratio of number of viable implantation sites to number of CL. This is consistent with previous studies relating increased litter size to increased ovulation rate (Wu et al., 1987).

In some of the non-pregnant gilts, gross ovarian morphological changes and large cystic follicles were observed at slaughter. At Centre A, 5 gilts failed to exhibit oestrus within 36 days after treatment. Several other epostane-treated gilts $(\mathrm{N}=7)$ showed oestrus, but remained anovulatory and their ovaries contained cystic follicles with thickened walls. These observations may explain why conception rate tended to be lower in these groups. Since epostane treatment continued until the expected day of oestrus, the normal steroidal processes of final follicular development may have been impaired and thereby contributed to the incidence of cystic follicles. Cessation of treatment a few days earlier before ovulation may be expected to result in less interference with follicular development and fertility, while still increasing ovulation rate. Variability in conception rates may also reflect artificial insemination as compared to natural mating.

Oral administration of epostane inhibited progesterone secretion as described for sheep (Ashworth et al., 1987; Webb, 1987) and pigs (Martin et al., 1987). Plasma progesterone concentrations had declined $4 \mathrm{~h}$ after feeding epostane, with recovery having begun at $12 \mathrm{~h}$. The inhibitory effect of oral epostane administration on plasma progesterone concentrations was dose related. In Phase I, epostane significantly reduced progesterone production, but did not appear to shorten the normal lifespan of the CL as reflected by plasma progesterone values. Oestrous cycle length was not altered by epostane treatment in Phase II. Thus, the inhibitory effect of epostane on progesterone production is due to enzymic inhibition and does not appear to alter the timing of luteolysis. Epostane treatment did not significantly alter cortisol secretion, even though adrenal progesterone is the precursor.

The mechanism by which epostane enhanced ovulation rate has not been established. Epostane acts on CL to inhibit competitively progesterone production, thereby altering the negative feedback equilibrium and leading to increased LH secretion in cattle (Peters \& Lamming, 1986). We propose that increased $\mathrm{LH}$ secretion is then responsible for recruitment of more follicles to develop for ovulation, as demonstrated previously by the effects of LH or epostane in other species (Garza et al., 1984; Webb, 1987). A detailed analysis of the secretion patterns for LH, FSH, oestradiol and progesterone and their interrelationships during Phase II of the present study will be reported separately.

We thank R. F. Gutheil, N. J. Meo, M. Barnes, W. Frank and D. Dixon for technical assistance. The work described was supported by the Sterling Research Group. 


\section{References}

Ashworth, C.J., Wilmut, I., Springbett, A. J. \& Webb, R. (1987) Effect of an inhibitor of $3 \beta$-hydroxysteroid dehydrogenase on progesterone concentrations and embryo survival in sheep. J. Endocr. 112, 205-213.

Blichfeldt, T. \& Almlid, T. (1982) The relationship between ovulation rate and embryonic survival in gilts. Theriogenology 21, 677-680.

Clark, J.R., Brazier, S.G., Winginton, L.M., Stevenson, G.R. \& Tribble, L.F. (1982) Time of ovarian follicle selection during the porcine estrous cycle. Theriogenology 18, 697-709.

Foxcroft, G.R. (1987) Follicular dynamics and its endocrine control in the sow. In Follicular Growth and Ovulation Rate in Farm Animals, pp. 191-205. Eds G. R. Foxcroft, J. F. Roche \& D. O'Callaghan. Martinus Nijhoff Publishers, Dordrecht.

Foxcroft, G.R. \& Hunter, M.G. (1985) Basic physiology of follicular maturation in the pig. J. Reprod. Fert., Suppl. 33, 1-19.

Garza, F., Shaban, M.A. \& Terranova, P.F. (1984) Luteinizing hormone increases the number of ova shed in the cyclic hamster and guinea-pig. J. Endocr. 101, 289-298.

Hunter, R.H.F. (1980) Physiology and Technology of Reproduction in Female Domestic Animals. Academic Press, London.

King, R.H. \& Williams, I.H. (1984) The influence of ovulation rate on subsequent litter size in sows. Theriogenology 21, 677-680.

Krey, L.C., Lu, K.-H., Butler, W.R., Hotchkiss, J., Piva, F. \& Knobil, E. (1975) Surgical disconnection of the medial basal hypothalamus and pituitary function in the rhesus monkey. II. GH and cortisol secretion. Endocrinology 96, 1088-1093.

Martin, P.A., Hammitt, D.G., Strohbehn, R.S. \& Keister, D.M. (1987) Induction of parturition in swine and epostane, a competitive inhibitor of 3-beta-hydroxysteroid dehydrogenase. J. Anim. Sci. 64, 497-506.

Nara, B.S. \& First, N.L. (1981) Effect of indomethacin and prostaglandin $\mathrm{F} 2 \alpha$ on parturition in swine. $J$. Anim. Sci. 52, 1360-1370.

Neter, J., Wasserman, W. \& Kutner, M.H. (1983) Transformations. In Applied Linear Regression Models, pp. 134-141. IRWIN, Homewood.

Peters, A.R. \& Lamming, G.E. (1986) The effect of epostane (Win 32729), an inhibitor of 3 betahydroxysteroid dehydrogenase, on luteal function and gonadotropin secretion in cows. Anim. Reprod. Sci. 10, 9l-98.

Pope, W.F. \& First, N.L. (1985) Factors affecting the survival of pig embryos. Theriogenology 23, 91-105.

SAS User's Guide (1985) Statistics. SAS Institute, Inc., Cary.

Snedecor, G.W. \& Cochran, W.G. (1980) Statistical Methods, 7 th edn. Iowa State University Press, Ames.

Webb, R. (1987) Increasing ovulation rate and lambing rate in sheep by treatment with a steroid enzyme inhibitor. J. Reprod. Fert. 79, 231-240.

Wu, M.G., Hentzel, M.D. \& Dziuk, P.J. (1987) Relationships between uterine length and number of fetuses and prenatal mortality in pigs. J. Anim. Sci. 65, $762-770$.

Received 30 January 1990 